\title{
GREAT GRAY OWLS APPARENTLY FEEDING ON FROGS ON ROADS AT NIGHT
}

RÓBERT W. NERO. Wildlife Branch. Box 14, 1495 St. James St. Winnipeg, Manitoba. R3H OW9

Observations by two separate parties in the same general area of Manitoba's Interlake Region in late August 1985, and a road-killed bird in April 1986, suggest owl predation on frogs during their nocturnal movements across roads.

Lori Thompson, Manitoba Fisheries Branch, reported that on 22 August 1985, between 9:00 p.m. and midnight, while driving from Ashern to Riverton, a distance of approximately $90 \mathrm{~km}$ (56 mi.), 15 to 25 owls were seen standing on the road. This was during a heavy rainfall with thunderstorm activity. He said that the owls were all large and several times he narrowly missed hitting them. The owls were assumed to be feeding on something on the roads (PR 228 and 233), but the observers did not stop to confirm this. Lori

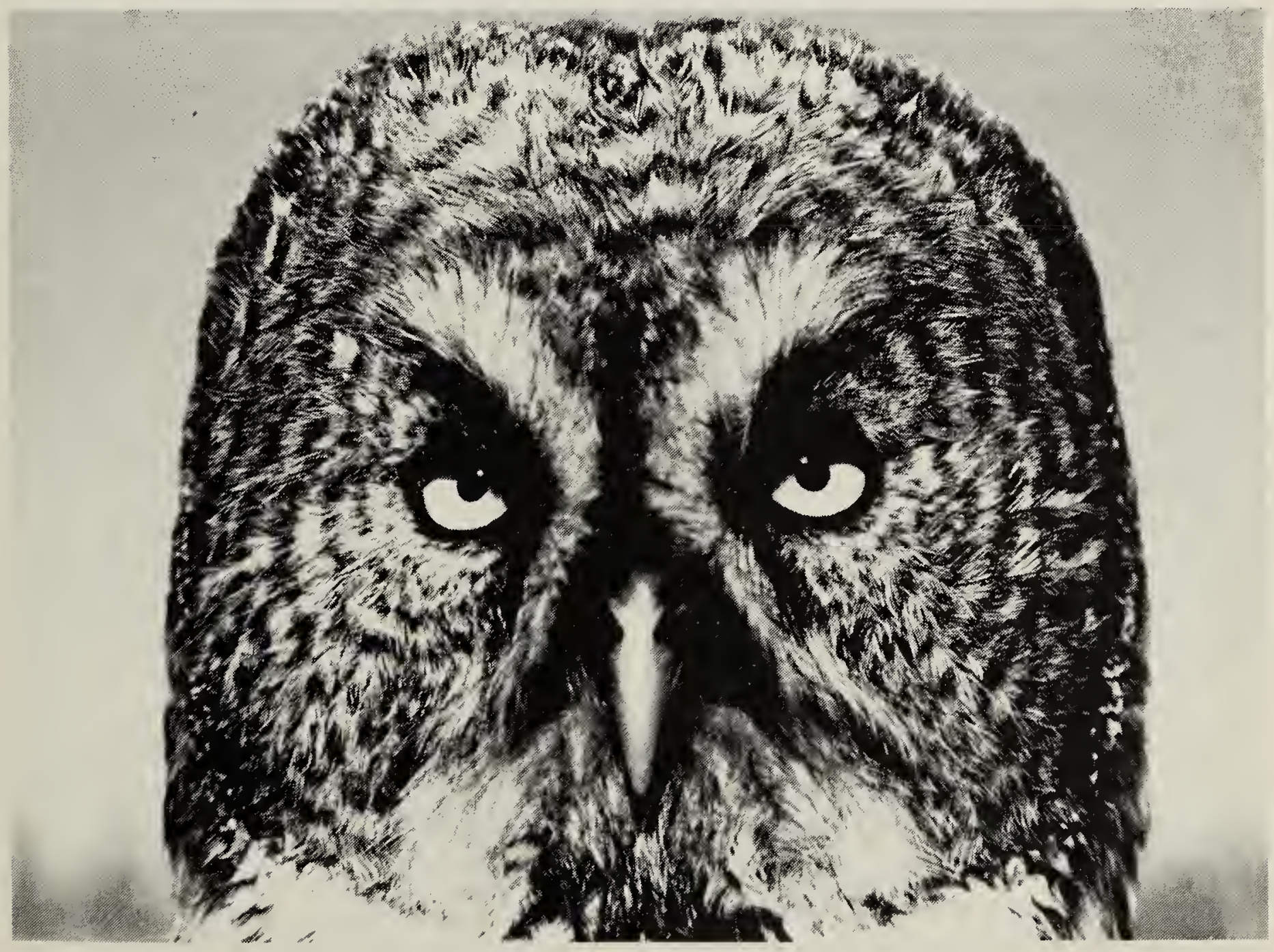


was accompanied by Ken Campbell and Anton Peterson, Fisheries Branch employees from Gimli.

Joyce Beaulieu, Winnipeg, phoned to tell me about seeing a massive movement of frogs, and six large owls, during a rain late in the evening of 30 August 1985, on roads between Riverton and Hecla village, a distance of about $45 \mathrm{~km}$ (28 mi.). This was between 7:34 and 9:30 p.m. According to Joyce, numerous large frogs covered the roads and she was dismayed by the number of frogs they were driving over. During the drive she also saw six large owls standing in the center of the road. She was convinced that two, one on the causeway and one on Hecla Island, were Great Gray Owls. In these cases, she had slowed down to get a careful look. The other owls, two of which were also on the causeway, appeared equally large, but seemed paler in color. Later that same night, Barney Beaulieu saw a large owl on the midline of the highway closer to Riverton. Joyce and Barney Beaulieu have travelled this route for the past 10 years, but have not previously seen anything similar.

The two large owls in this area, the Great Gray Owl and the Great Horned Owl, are both known to feed on frogs, especially when pressed for food. 123 Snowshoe Hares and Sharp-tailed and Ruffed grouse populations in this region are notably low, and have been for the past 3 years. Voles in the Pinawa area, a considerable distance southeast, crashed in mid-winter 1984-85, reaching an alltime low according to Steve Mihok, who guessed that it would take a year or two for these populations to recover (pers. comm., 1984). Several radio-marked Great Gray Owls that had bred successfully in southeastern Manitoba in summer 1984, emigrated over winter to more northerly areas. Those few that remained failed to breed in summer 1984, presumably because of the scarcity of voles. Ray Tuokko reported that Great Horned Owls at a nest near Lac du Bonnet in summer 1985 subsisted mainly on a wide variety of small birds (pers. comm., July 1985).

The frequency of frogs as prey for the Great Gray Owl has been regarded as low, but during non-nesting situations observations of predation are practically nil. Moreover, the relatively soft bones of frogs may not always be found in owl pellets. Evidence that the Great Gray Owl sometimes preys heavily on frogs, however, was obtained recently. An immature female, killed near Pointe du Bois, Manitoba about 10:30 p.m., 17 April 1986, had six Wood Frogs and a Masked Shrew in its stomach. This owl had been sitting on the road adjacent to a tamarack bog when it was accidentally struck and killed by a car driven by Mrs. Dave Cavanagh. The dead bird was found the next day by Dave Cavanagh who kindly brought it to me.

The above data lend support to the speculation that Great Gray Owls, and possibly Great Horned Owls, when desperate for food take advantage of nocturnal movements of frogs as a prey source.

\section{Acknowledgments}

I am indebted to Joyce Beaulieu and Lorimer Thompson for calling my attention to their observations, and to Dave Cavanagh for ensuring that a road-killed Great Gray owl was recovered and made available for study.

1 BENT, A.C. 1938. Life histories of North American birds of prey. Part 2. Bull. 170, U.S. Natl. Mus, Reprinted 1961, Dover Publ. Inc., N.Y.

2 CRAMP, S. (ED.). 1985. Handbook of the birds of Europe, the Middle East and North Africa. Vol. 4. Oxford University Press, New York.

3 NERO, R.W. 1980. The Great Gray Owl, phantom of the northern forest. Smithsonian Institution Press, Washington, D.C. 